UDC 621.2.082.18

M. A. Shilov ${ }^{1,2}$, P. V. Korolev ${ }^{1,2}$, S. V. Fomin ${ }^{2}$, L. B. Maslov ${ }^{2}$

\title{
ROLLING WEAR OF NANOSTRUCTURED ELASTOMERS FOR PNEUMATIC TIRES
}

\author{
${ }^{1}$ Ivanovo State Power University named after V. I. Lenin, \\ 34 Rabfakovskaya St., Ivanovo, 153003, Russia. E-mail: Mshilov@yandex.ru \\ ${ }^{2}$ Vyatka State University, \\ 36 Moskovskaya St., Kirov, 610000, Russia
}

The effect of carbon nanotubes, which inclined to displaying mesomorphism, introduced into elastomers on rolling-sliding wear was investigated. Some tentative conclusions about the correlation between a change in the structure of an elastomeric material and its wear were drawn on the basis of the study of the effect of rolling speed and temperature upon the wear. The tasks for further studies of wear depending on the slip angles were set by the authors. They are meant to be run on a tribological stand and simulated using specialized software.

Key words: wear, friction, elastomers, pneumatic tires, carbon nanotubes.

DOI: $10.18083 /$ LCAppl.2019.2.85

\author{
М. А. Шилов ${ }^{1,2}$, П. В. Королев ${ }^{1,2}$, С. В. Фомин ${ }^{2}$, Л. Б. Маслов ${ }^{2}$
}

\section{ИССЛЕДОВАНИЕ ИЗНОСА НАНОСТРУКТУРИРОВАННЫХ ЭЛАСТОМЕРОВ ДЛЯ ПНЕВМАТИЧЕСКИХ ШИН ПРИ КАЧЕНИИ}

\author{
${ }^{1}$ Ивановский государственный энергетический университет им. В. И. Ленина, \\ ул. Рабфаковская, д. 34, 153003 Иваново, Россия. E-mail: Mshilov@yandex.ru \\ ${ }^{2}$ Вятский государственный университет, \\ ул. Московская, д. 36, 610000 Киров, Россия
}

\begin{abstract}
В работе обсуждаются результаты исследования влияния введения в структуру эластомеров углеродных нанотрубок, склонных к мезоморфизму, на износ при качении с проскальзыванием. Полученные результаты по изучению влияния на износ скорости качения и температуры позволили сделать предварительные выводы о влиянии изменения структуры эластомерного материала на его износ. Авторами поставлены задачи дальнейших исследований износа в зависимости как от углов увода с помощью трибологического стенда, так и моделирования процесса численными методами $в$ специализиорованном программном комплексе.
\end{abstract}

Ключевые слова: износ, трение, эластомеры, пневматические шины, углеродные нанотрубки. 


\section{Introduction}

Since Mr. Dunlop patented his pneumatic tire in 1888, there has been going a constant race to improve the design and the material of the pneumatic tire. A pneumatic tire is made up of metal elements (steel belt or cord, bead bundle) as well as elastomer elements. In the manufacture of tire tread elastomers having high wear resistance, hardness and elasticity are used. The physico-mechanical properties of elastomers are constantly being improved. Processing of synthetic rubbers leads to their instability and the loss of the required operational properties $[1,2]$. It is possible to stabilize rubbers with the help of potential mesogenic compounds [3]. In a previous paper [4], we evaluated the sliding wear resistance of tread rubber elastomers. To stabilize the elastomers, carbon nanotubes (CNT) were used, as it was described in the review article [5] by A. Sonin et al. The nanotubes proved to be a rather promising material possessing anisotropic properties characteristic of mineral liquid crystals. The CNT anisotropy manifests itself in the tube ends' orientation resulting in their strong interaction with the molecules of the tread rubber. As a result, the stabilization of elastomers leads to a decrease in energy expenditures for friction and wear. Based on the above said, the purpose of the work was to study the effect of nanotube stabilization of rubbers on the extent of rolling wear.

\section{Experiment}

As test samples we studied regular elastomers $(E l)$, as well as nanostructured elastomer samples $(N E l)$ (Fig. 1) of $d=2 R=50 \mathrm{~mm}$ outer diameter, and $h=10 \mathrm{~mm}$ in height. The counterbody material was selected from the variety of road top asphalt concrete mixes used in road construction for Central Russia. Counterbody material properties are listed in Table 1.

Table 1. Physico-mechanical properties of the asphalt concrete sample

\begin{tabular}{|l|c|c|c|}
\hline \multicolumn{1}{|c|}{ Material } & Modulus of elasticity E, MPa & Density $\rho, \mathrm{kg} / \mathrm{m}^{3}$ & Poisson's ratio $\mu$ \\
\hline $\begin{array}{l}\text { Grade I-II dense asphalt concrete based on hot } \\
\text { Type A BND60/90 bitumen mix. }\end{array}$ & 5000 & 2350 & 0.20 \\
\hline
\end{tabular}

The dimensions of the abradable and abrasive samples were the same. The properties of the nanostructured elastomer were presented in a previous work [4].

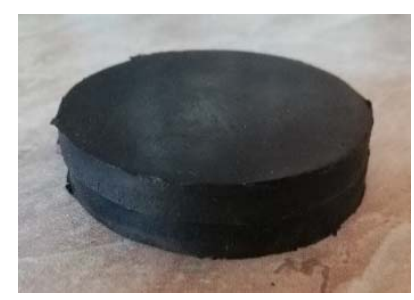

Fig. 1. Nanostructured elastomer sample

The rolling with slipping wear tests were performed on the UMT-2168 Unitrib all-purpose friction test bench, designed by IMASh RAN and Tochpribor scientists (Ivanovo, Russia) [4] (Fig. 2). The friction test scheme is given in Fig. 3 .

Through bearings in the test bench housing (5) goes a hollow shaft (3), inside of which there is a rod (4). A disc (8) is pivotally mounted on the rod (4), through a ring (6) and a flexible transmission (9), the disc is connected to the shaft (3). The aforesaid shaft (3) by means of a lever (10) acts upon an elastic element (11) of the load cell. The membrane actuator (1) transfers axial load to the rod (4) and the disc (8). Either cylindric samples (7) or friction-pair test chambers are fixed to the disc (8). In some cases the disc (8) can be rigidly coupled to the ring (6). There are internal water passages to cool the disc (8). The samples are fed by moving the housing (5) along a bed frame (18) by rotating a handle (19).

Through the use of special attachments, various test modes can be implemented. The removable chambers make it possible to test samples in a variety of modes e.g. shaft-sleeve or shaft-pin either in a revolving or rocking motion of the shaft. In these cases the test bench is driven by a crank (16), mounted on a shaft (17) of the gearbox (13). In any case the load is transferred to the samples by the independent pneumatic actuator (1). The disk's (14) number of revolutions (the friction path length) is measured by a sensor (20). The electric motor's (2) RPMs are switched by a sensor (21). 
The shaft's (12) RPMs of the friction test bench can be smoothly adjusted in the 50-3000 rpm range, while the load upon the samples can be adjusted in the $0.02-5 \mathrm{kN}$ range by changing the air pressure in the pneumatic actuator (1).
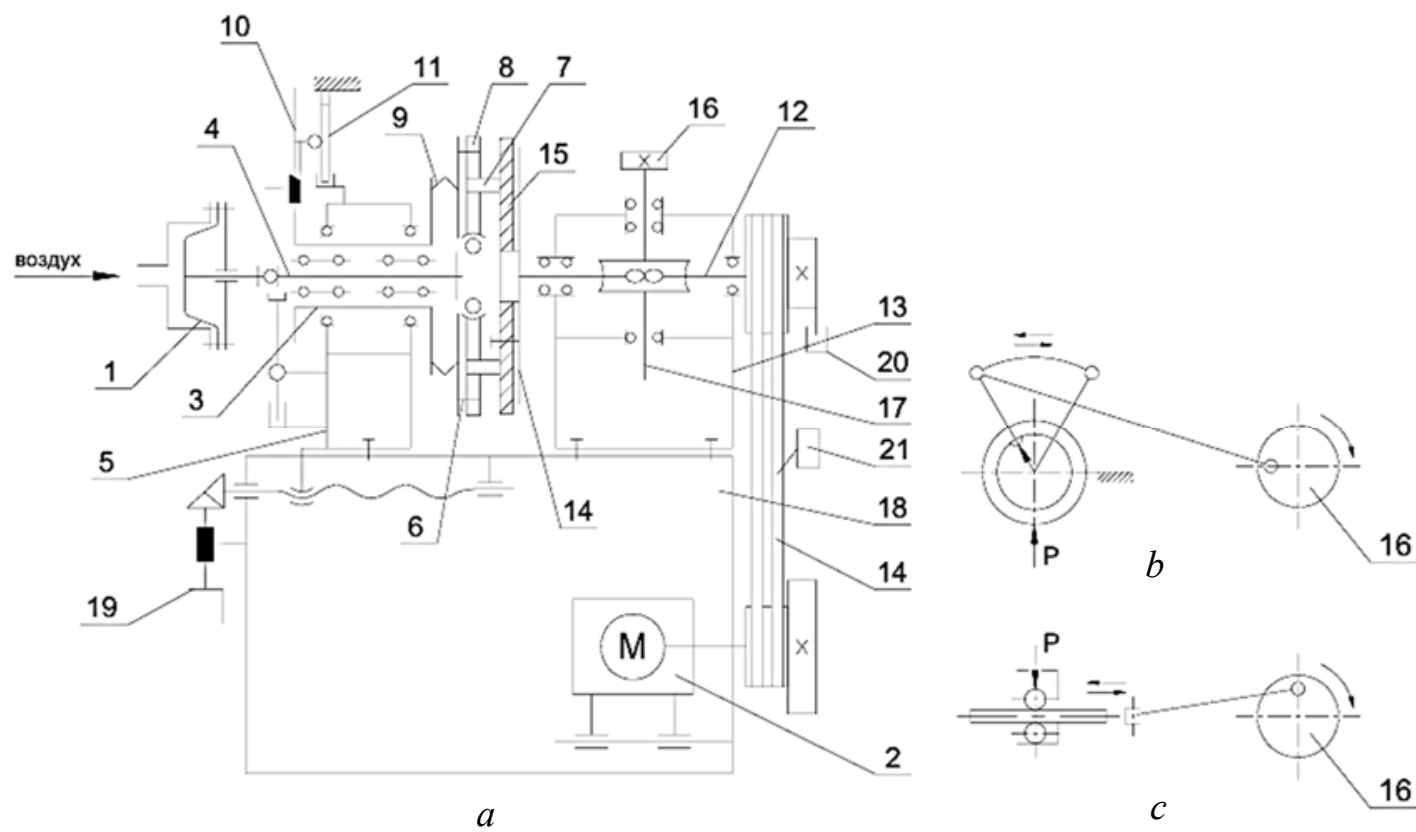

Fig. 2. Schematic diagram of the UMT-2168 Unitrib tribometer [4]:

$a$ - general diagram; $b$ - test circuit at oscillatory motion; $c$ - test circuit at reciprocating motion
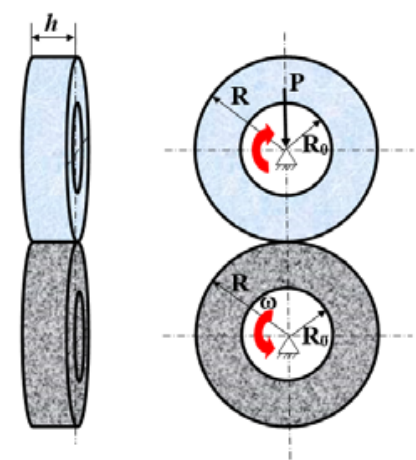

Fig. 3. Friction scheme

The temperature in the friction zone was recorded with a Fluke Ti400 thermal imager. The temperature was measured in the $40-90{ }^{\circ} \mathrm{C}$ range. Temperature control was not used.
The samples were tested according to the following preparatory procedure:

1. Friction pairs degreasing,

2. Samples abrasion until a stationary rolling friction mode was achieved,

3. Measuring linear dimensions and weighing the sample before and after abrasion.

While in the stationary mode, the friction torque $M_{f r} N \cdot m$, normal load $P, N$ and the corresponding friction path length $L, \mathrm{~km}$ were measured. The samples were abraded in the $60-80 \mathrm{~km} / \mathrm{h}$ speed range. Measurement errors are given in Table 2.

The contact load varied from 3.0 to $3.5 \mathrm{kN}$, which corresponded to the actual car wheel load at an average car weight of 1200-1400 kg. 
Table 2. Measurement errors

\begin{tabular}{|l|c|c|}
\hline \multicolumn{1}{|c|}{ Measured value } & Measurement range & Error \\
\hline Friction path length, $\mathrm{km}$ & 1000 & \pm 0.001 \\
\hline Test time, min & $540-600$ & \pm 1 \\
\hline Normal load, $\mathrm{kN}$ & $3.0-3.5$ & \pm 0.01 \\
\hline Rolling speed, $\mathrm{km} / \mathrm{h}$ & $60-80$ & \pm 0.1 \\
\hline Elastomer surface temperature, ${ }^{0} \mathrm{C}$ & $40-90$ & \pm 0.1 \\
\hline
\end{tabular}

\section{Results and discussion}

The pneumatic tires wear tests demonstrated that an increase of temperature at all loads and speeds led to the decrease the nanostructured samples' wear, see Fig. 4.

As it is evident from the correlation between the elastomers wear and the temperature, with the increase of both the rolling speed and the temperature in the contact area, all the tested samples demonstrated linear increase of wear. The greatest wear $(1.12 \mathrm{~mm} / 1000 \mathrm{~km})$ was demonstrated by sample $E l$ when rolling at
$80 \mathrm{~km} / \mathrm{h}$. Once nanostructures were introduced into the elastomers, a decrease of wear was recorded throughout the complete range of speeds and temperatures. The maximum decrease of wear (twofold) was recorded for the nanostructured sample when rolling at the speed of $80 \mathrm{~km} / \mathrm{h}$.

To obtain additional data on the correlation between wear and the rolling speed $v$ and normal load $P$ at $T=60{ }^{\circ} \mathrm{C}$, we ran extra tests on the elastomer samples (Fig. 5).

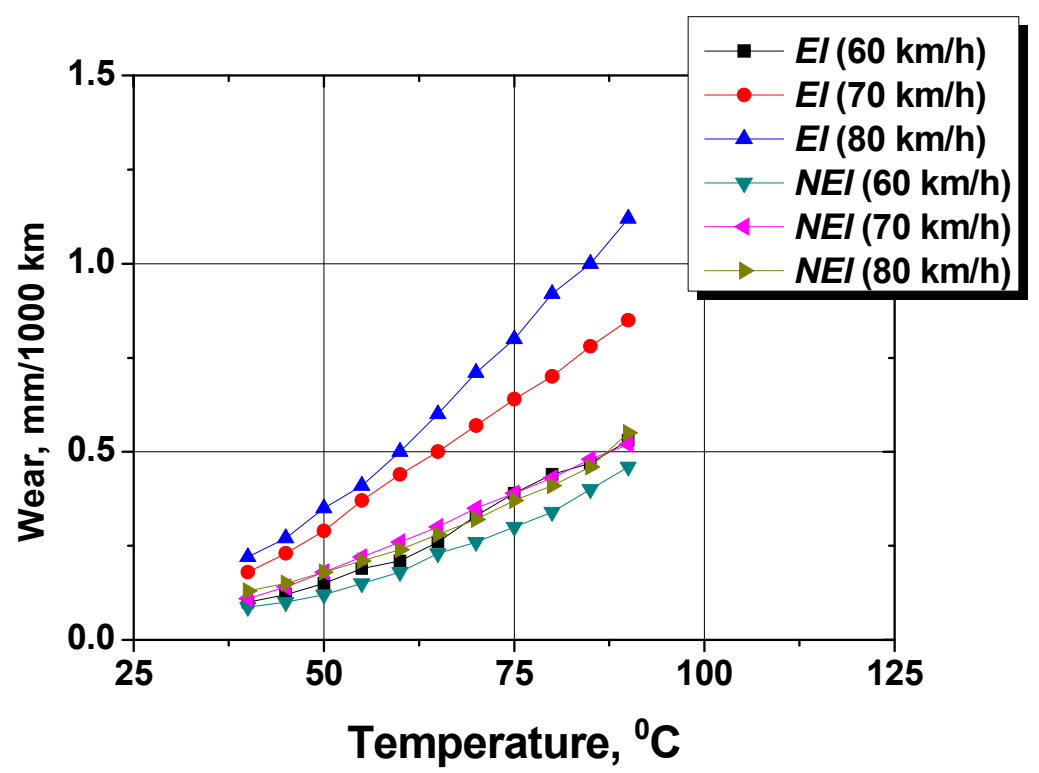

Fig. 4. Correlation between the extent of elastomers wear and rolling speed and temperature. Normal load $P=3300 \mathrm{~N}$ 


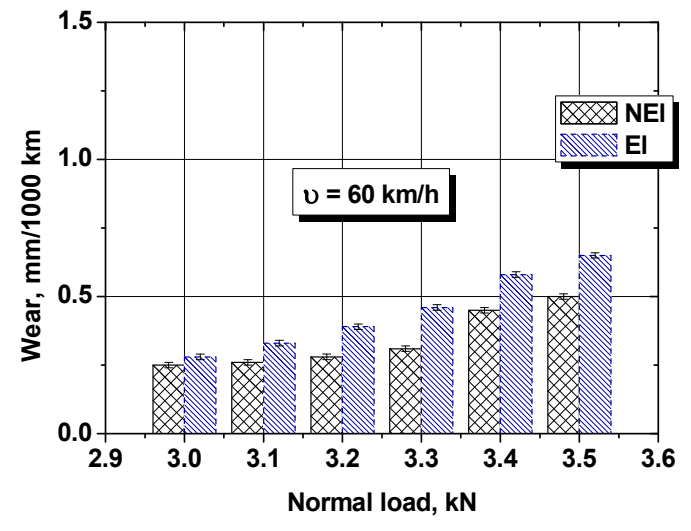

$a$

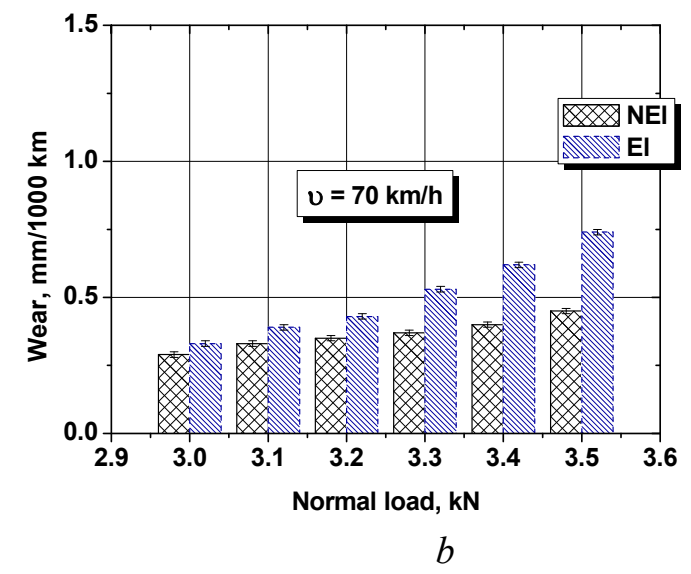

$b$

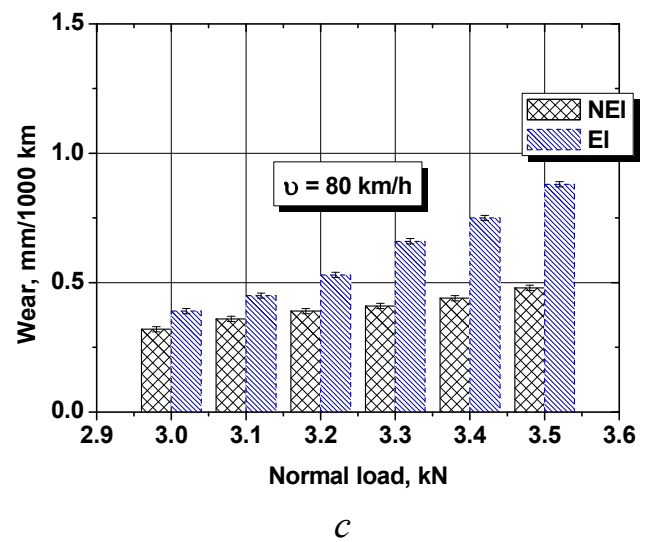

Fig. 5. Wear/normal load correlation histograms. Temperature $\mathrm{T}=60^{\circ} \mathrm{C}$, rolling speed $60-80 \mathrm{~km} / \mathrm{h}$

The wear histograms showed that nanostructured elastomers consistently demonstrated less wear throughout the entire range of normal loads at constant $T=60^{\circ} \mathrm{C}$ temperature. With an increased load, the wear of regular elastomer samples increased as well from 0.26 to $0.65 \mathrm{~mm} / 1000 \mathrm{~km}(\mathrm{v}=60 \mathrm{~km} / \mathrm{h})$, from 0.33 to $0.74 \mathrm{~mm} / 1000 \mathrm{~km}(v=70 \mathrm{~km} / \mathrm{h})$, from 0.38 to $0.88 \mathrm{~mm} / 1000 \mathrm{~km}(v=80 \mathrm{~km} / \mathrm{h})$. As the results demonstrated the wear rate of the tested elastomers decreased with the speed increase. The wear rate changes for the nanostructured elastomer samples was recorded at: from 0.24 to $0.5 \mathrm{~mm} / 1000 \mathrm{~km}(\mathrm{v}=60 \mathrm{~km} / \mathrm{h})$, from 0.28 до $0.45 \mathrm{~mm} / 1000 \mathrm{~km}(\mathrm{v}=70 \mathrm{~km} / \mathrm{h})$, from 0.33 tо $0.48 \mathrm{~mm} / 1000 \mathrm{~km}(\mathrm{v}=80 \mathrm{~km} / \mathrm{h})$. The obtained data proved that the use of nanostructures in elastomers reduces not only the wear, but also the wear rate.

\section{Conclusions}

An important scientific task of reducing the wear of elastomers used as pneumatic tire tread material has been solved. The factors affecting tire fatigue wear have been determined. The drawn elastomer wear histograms have demonstrated reduced wear rate with the increase of the rolling speed at the normal load. A speed increase from 60 to $80 \mathrm{~km} / \mathrm{h}$ reduces the wear rate for a regular elastomer sample from three-fold to two-fold. However, for nanostructured elastomers, this reduction is from 1.6 to 1.45 times. The resulting linear correlation between the wear and the temperature (Fig. 4) steadily increases for both regular and nanostructured elastomer samples. The wear of nanostructured elastomer samples has diminished throughout the entire temperature range as compared to the regular elastomers.

The next research the authors are planning to undertake is forecasting the wear of nanostructured elastomeric materials by applying the finite element method in a specialized software suite. The following step will be the experimental study of elastomers abrasion (wear) depending on the slip angle and the kinds of the friction surface. 


\section{References}

1. Nikulin S.S., Pugacheva I.N., Chernikh O.N. Composite materials based on styrenebutadiene rubber. Moscow : Publisher «Akademiya Estestvoznaniya», 2008, 145 p. (in Russ.).

2. Ntziachristos L., Boulter P. Road vehicle tyre and brake wear. Road surface wear. EMEP/EEA air pollutant emission inventory guidebook. Copenhagen, European Environment Agency, 2009, Part B, 32 p.

3. Fokin D.S. Physical and chemical properties and application of mesogene derivatives of the fenylbenzoate, azo-and azoxybenzene with polar terminal substituents. $\mathrm{PhD}$ thesis (Chem.) Ivanovo : Ivanovo State University of Chemistry of Technology, 2011, 142 p. (in Russ.).
4. Shilov M.A., Maslov L.B., Korolev P.V. Study of wear resistance of nanostructured elastomers used as protectors in pneumatic tyres. Liq. Cryst. and their Appl., 2018, 18 (1), 73-78 (in Russ.)].

DOI: $10.18083 /$ LCAppl.2018.1.73.

5. Sonin A.S., Churochkina N.A., Kaznacheev A.V., Golovanov A.V. Liquid crystals of carbon compounds. Liq. Cryst. and their Appl., 2017, 17 (3), 5-28 (in Russ.)]. DOI: 10.18083/LCAppl.2017.3.5.

Поступила в редакцию 15.05.2019 2. Received 15 May 2019 